\title{
Frequencies of circulating myeloid derived suppressor cells and dendritic cells in Egyptian patients with chronic Hepatitis C Virus infection undergoing treatment with IFN- $\alpha$-based therapy
}

Mohamed L Salem", Abdel-Aziz A Zidan', Mohamed Abou Senna', Abdel Raouf Abou Al-Azm', Hasan Albatei ${ }^{1}$, Maha Aldemelaawy², Mohamed Attia'

From Society for Immunotherapy of Cancer 28th Annual Meeting

National Harbor, MD, USA. 8-10 November 2013

\section{Background}

Hepatitis C Virus (HCV) is epidemic in Egypt and causes chronic hepatitis. Anti-HCVtherapy (IFN- $\alpha$ and Ribavirin) is only effective in $60 \%$ of patients with chronic $\mathrm{HCV}$ infection. This failure which is often associates with suppression of immunity results in progression of the disease and the development of hepatocellular carcinoma. Recent studies including ours have shown a positive correlation between accumulation of myeloid derived suppressor cells (MDSCs) and suppressed immunity in cancer and other diseases.

\section{Aim}

To assess the frequency of myeloid cells, including MDCS and dendritic cells (DCs) in chronic HCV patients and correlate it with the responses of the patients to IFN$\alpha$-bases therapy.

\section{Methods}

Peripheral blood was drawn from 80 patients with chronic $\mathrm{HCV}$ infection (mean age $=41.5 \pm 6.51$ years; male/female: $60 / 20$ ) and from 10 healthy volunteers (mean age $=28.5 \pm$ 3.81 years; male/female: $8 / 2$ ). The study was conducted from January 2011 to April 2013. The patients were categorized into responders and non-responders based on viral titer and the clinical data was collected and analyzed for each patient. Frequency of the cells was assessed by flow cytometry and IL-2 was assessed by ELISA.

\section{Results}

We defined MDSC population as Lin-/HLA-DR-/CD33 $+/ \mathrm{CD} 11 \mathrm{~b}+$. We also found increases in the frequency of MDSC. The high levels of MDSC was associated with increases in the frequency of DCs and T cells (CD4+ and $\mathrm{CD} 8+$ ), as well as with the differential count of lymphocytes, and monocytes. It was associated, however, with decreases in the total numbers of the total number of white blood cells, granulocytes, and platelets. The total Bilirubin level, and hemoglobin, in all IFN- $\alpha$ Responders and Non-Responders when compared with healthy donors. Interestingly, the frequencies of MDSC and DCs in IFN- $\alpha$-responders were lower than in those in nonresponders. More interestingly, the levels of MDSC measured 4-6 months of IFN- $\alpha$ treatment of responders was much lower than those during treatment. We found that there was no correlation between MDSCs, and the liver enzymes AST and ALT.

\section{Conclusions}

Chronic HCV patients showed high levels of MDSCs regardless IFN- $\alpha$ therapy. The responders have the tendency of lower MDSC levels than non-responders. MDSCs can use as biomarker of responsiveness to IFN-based therapy. As such, identifying novel effective therapeutic that can target MDSCs would improve clinical outcomes in $\mathrm{HCV}$ patients.

'Faculty of Science, Tanta University, Tanta, Egypt

Full list of author information is available at the end of the article

\section{Authors' details}

Faculty of Science, Tanta University, Tanta, Egypt. ${ }^{2}$ Biomedical Technology Department, City of Scientific Research and Applied Technologies, Alexandria, Egypt. 
doi:10.1186/2051-1426-1-S1-P248

Cite this article as: Salem et al:: Frequencies of circulating myeloid derived suppressor cells and dendritic cells in Egyptian patients with chronic Hepatitis C Virus infection undergoing treatment with IFN- $\alpha$ based therapy. Journal for ImmunoTherapy of Cancer 2013 1(Suppl 1):P248.

Submit your next manuscript to BioMed Central and take full advantage of:

- Convenient online submission

- Thorough peer review

- No space constraints or color figure charges

- Immediate publication on acceptance

- Inclusion in PubMed, CAS, Scopus and Google Scholar

- Research which is freely available for redistribution

Submit your manuscript at www.biomedcentral.com/submit 